\title{
The study of the remyelinating effect of leukemia inhibitory factor and melatonin on the toxic cuprizone model of demyelination of murine cerebellar cells culture in vitro
}

Rodnichenko A. E., Labunets I. F.

State Institute of Genetic and Regenerative Medicine National Academy of Medical Sciences of Ukraine, Kyiv, Ukraine e-mail: arodnichenko@ukr.net

\section{ABSTRACT}

The cuprizone model of toxic demyelination in vitro is widely used to study de-and remyelination in the CNS, as well as to address the issues of finding potential compounds that affect myelination of neuron axons.

THE AIM OF THE STUDY was to investigate the role of recombinant human leukemia inhibitory factor (rhLIF) and melatonin in remyelination, using the cuprizone demyelination model in vitro.

METHODS. To study the features of the demyelination and remyelination processes of neuronal axons, the culture of dissociated cerebellar cell culture of the 7-day-old FVB/N lineage mice was used. To detect the myelin sheaths, a histochemical staining with a Sudan Black B was used. To identify oligodendrocytes, immunocytochemical staining of 28-30-day old cerebellar cells cultures for oligodendrocytes marker Olig2 was performed.

RESULTS. The direct effect of the demyelinating factor of cuprizone and remyelination agents (rhLIF and melatonin) on oligodendrocytes in vitro was confirmed. The remyelinating effect of LIF and melatonin on the restoration of myelination processes in dissociated cerebellar cell culture using histochemical and immunocytochemical staining has been revealed.

CONCLUSIONS. Cuprizone-induced demyelination in vitro is associated with the death of Olig2 $2^{+}$oligodendrocytes and loss of myelin formation. rhLIF and melatonin prevented the loss of oligodendrocytes and, consequently, reduced the destruction of myelin membranes.

KEY WORDS: cerebellum; cuprizone; demyelination; remyelination; rhLIF; melatonin

Demyelinating diseases of the central nervous system are characterized by the destruction of the myelin sheath of nerve fibers, resulting in a violation of the nerve impulses and inhibition of motor activity [1-4]. Multiple sclerosis is the most common demyelinating disease. To study the pathogenesis of multiple sclerosis and to find new therapeutic approaches, it is necessary to apply adequate experimental models of this disease [4-9]. Recently, great attention is paid to models that are able to reproduce the pathologies of the nervous system in vitro. It should be noted that in vitro models are systems that allow evaluating cell functions and processes that occur at different stages of their development, as well as the direct effect of both demyelinating and remyelinating factors [10,
11]. The search of new neuroprotective agents, whose influence on the dynamics of the nervous system is multifactorial, is relevant.

Biologically active compounds, in particular cytokines and hormones, are promising for the recovery of myelination in demyelinating pathologies of the nervous system. Among the cytokines, the multifunctional leukemia-inhibitory factor (LIF) deserves attention, which affects neuronal cells not only in normal, but also in conditions of the damaged nervous system [12-14]. LIF affects the proliferation of oligodendrocyte precursors and promotes differentiation in oligodendrocytes [13]. The expression of myelin basic protein (MBP) in the cerebral cortex of mice with a cuprizone-induced demyelination model after administration of LIF was 
shown [6]. The anti-apoptotic effect of LIF on oligodendrocytes is associated with a decrease in the manifestations of neuroinflammation due to inhibition of proinflammatory cytokine production of TNF-alpha [15] In neural progenitors and newly formed neurons, LIF inhibits caspasemediated apoptosis [16]. Improvement of myelination of the axons of brain neurons was shown after intraperitoneal administration of LIF at a dose of $25 \mu \mathrm{g} / \mathrm{kg}$ or $50 \mu \mathrm{g} / \mathrm{kg}$ to inbred mice with an experimental model of demyelination [17]. Earlier in our studies, the neuroprotective effect of rhLIF on the mice with cuprizone-induced model of toxic demyelination in vivo depending on the age of the animals was shown [18].

The effectiveness of the reparative processes in the brain in the pathologies of the nervous system depends on the influence of factors of macro environment, in particular hormones [19]. Melatonin exhibits a wide range of biological activity, in particular, its participation in antioxidant protection of the organism is shown. This hormone, one of the strongest direct antioxidants, absorbs endogenous free radicals (hydroxyl radical, superoxide radical anion, singlet oxygen, nitric oxide) and protects cells macromolecules (proteins, lipids, nuclear and mitochondrial DNA) from oxidative damage. Melatonin also acts as an indirect antioxidant, stimulating the activity of antioxidant enzymes in the brain of animals with neurodegenerative diseases [20-22].

It is known that antioxidants are able to prevent cell death induced by various toxins on the proteins of the mitochondrial pores. It is free radicals that lead to the opening of mitochondrial pores, through which cytochrome $\mathrm{C}$ that activates cytoplasmic proteolytic proteins (caspases) is released from the mitochondria in the cytosol. This leads to enhanced proteolysis of cellular protein mediated by caspases, which plays a significant role in the development of apoptosis. The direct suppressive effects of melatonin on the pores of mitochondria is shown [21]. In the study of Kashani I. R. et al., the restoration of myelination of axons of brain neurons after intraperitoneal administration of the melatonin to mice with an experimental toxic cuprizone model of demyelination, with an analysis of the expression of genes of mitochondrial proteins of myelin-producing cells and ultrastructural changes in mitochondria was demonstrated [23]. There is data on amplification under the influence of melatonin of the proliferative potential of neural stem cells (NSCs) in the brain and their differentiation in the neurons [24, 25]. There are studies suggesting that the pineal hormone melatonin suppresses the development of Parkinson's disease or parkinsonism in experimental and clinical use [26, 27].

It should be noted that in our previous studies on the cuprizone model of toxic demyelination in vitro, it was shown that after administration of the neurotoxin cuprizone for 48 hours at a dose of $25 \mu \mathrm{M}$, the loss of Olig2-positive oligodendrocytes was observed, accompanied by demyelination of the cerebellum neuron axons $[28,29]$. Therefore, at this stage, the purpose was to study the possibility of direct action of rhLIF and melatonin on oligodendrocytes and in vitro myelination processes.

\section{MATERIALS AND METHODS}

To study the features of the processes of myelination, demyelination and remyelination of neuron axons, the culture of dissociated cerebellar cells of the 7-day-old FVB/N mice $(n=27)$ was used. Euthanasia of newborn mice was performed by ether overdosing. All studies with experimental animals were carried out in compliance with the legislation and principles of bioethics: the Law of Ukraine «On the Protection of Animals from Cruelty» (dated February 21, 2006), «European Convention for the Protection of Vertebrate Animals Used for Experimental and Other Scientific Purposes» (Strasbourg, 1986).

Isolation of the cerebellum was carried out on ice, in sterile conditions. The cerebellum was placed in a medium containing $90 \%$ of DMEM medium, $10 \%$ horses serum, inactivated at $56{ }^{\circ} \mathrm{C}$ for 30 minutes, $6 \mathrm{~g} / \mathrm{L}$ glucose, $100 \mathrm{U} / \mathrm{mL}$ penicillin, and $100 \mu \mathrm{g} / \mathrm{mL}$ streptomycin (all reagents Sigma, USA). Dissociated cells were obtained by mincing the cerebellum with scissors in $0.25 \%$ trypsin solution (Sigma, USA) after pre-washing samples in a phosphate buffered saline (PBS) with antibiotics PenStrep (Sigma, USA). The resulting suspension was left for 5 minutes at $+37^{\circ} \mathrm{C}$ with constant shaking, followed by mechanical dissociation using pipettes of different diameters. The dissociated cerebellar cells were counted and transferred to $35 \mathrm{~mm}$ cell culture dishes precoated with poly-L-lysine at a seeding density of $2 \cdot 10^{6} \mathrm{cell} / \mathrm{s} / \mathrm{cm}^{2}$. Cell cultivation was carried out in an complete culture medium that contained $90 \%$ DMEM, $10 \%$ horse serum (Sigma, USA), $6 \mathrm{~g} / \mathrm{L}$ glucose, bovine insulin (Sigma, USA) $10 \mu \mathrm{g} / \mathrm{ml}$, $100 \mathrm{U} / \mathrm{mL}$ penicillin, and $100 \mu \mathrm{g} / \mathrm{mL}$ streptomycin under standard conditions in a $\mathrm{CO}_{2}$ incubator at a temperature of $+37^{\circ} \mathrm{C}$ and in a humidified atmosphere with $5 \%$ of $\mathrm{CO}_{2}$.

In our previous studies, it was found that a significant death of Olig2+ oligodendrocytes compared with control cultures was observed only with the use of cuprizone on the 18th day of cultivation of the dissociated culture of the cerebellar cells [28]. Therefore, on the $18^{\text {th }}$ day of cultivation, cuprizone (Sigma, USA) at a dose of $25 \mu \mathrm{M}$ was introduced in the culture for 48 hours. After 48 hours, a medium containing recombinant human LIF $(20 \mathrm{ng} / \mathrm{mL})$ or melatonin $(10 \mu \mathrm{g} / \mathrm{mL})$, was introduced into the cell culture during three days. The cultivation was carried out during 28-30 days with the replacement of the growth medium twice a week. Assessment of condition of cultured cells were performed with an inverted microscope IX71 (Olympus, Japan) in phase contrast mode.

To detect myelin sheaths, a histochemical staining with Sudan of black B was used. 28-30-day cultures of the cerebellar cells were washed with PBS and fixed with $1 \%$ paraformaldehyde solution on $0.1 \mathrm{M} \mathrm{PBS}$ for one hour. Dehydration was then carried out in $25 \%, 50 \%$ and $70 \%$ ethanol solutions for 5 minutes in each solution. The stained sections were examined using an inverted microscope IX71 (Olympus, Japan) in phase contrast mode.

To identify oligodendrocytes, the culture was immunocytochemically stained for oligodendrocyte marker Olig2. Cultures of 28-30 days were fixed with $4 \%$ paraformaldehyde solution for 30 minutes. After washing, the cell culture was blocked in $0.1 \mathrm{M} \mathrm{PBS}(\mathrm{pH}=7.4)$ with $0.5 \%$ bovine serum albumin and $0.3 \%$ Triton X-100 (Sigma, USA). Within 48 hours at $+4{ }^{\circ} \mathrm{C}$, cell culture was incubated with primary rabbit monoclonal antibodies to Olig2 (Chemicon, USA) in dilution 1:200. Primary antibodies were visualized with secondary anti-rabbit AlexaFluor 488-conjugated antibodies (Invitrogen, USA) in dilution 1:1000. Cell nuclei were stained with Hoechst 33342 dye (Invitrogen, USA) in dilution 1:5000. Microscopy was performed using an inverted fluorescence microscope Axio Observer A1 equipped with a digital camera AxioCam ERc 5s with ZEN 2012 and AxioVision 4.8 software, using the fluorescence filters 21HE (for Hoechst) and 56NE (for AlexaFluor 488) (Carl Zeiss, Germany). Cell counting was performed in 5 random fields of view of the culture of each experimental group.

To clone the human LIF gene, we used the technology for obtaining the c-DNA gene with a reverse transcriptase reaction with subsequent amplification of c-DNA using a polymerase chain reaction [12]. It has been established that human and mice LIF exhibit up to $80 \%$ homologous sequences; human LIF is capable of binding to LIF receptors on mouse cells and activating them [29].

Statistical analysis was performed using the Statistica 7.0 (StatSoft Inc., USA) software. The differences between the groups was assessed using Student's t-test. The results are presented as means and standard error of mean $(\mathrm{M} \pm \mathrm{m})$. The difference between the parameters was considered statistically significant at a value of $p<0.05$.

\section{RESULTS AND DISCUSSION}

Our previous studies confirmed the process of myelination, which is impossible without the presence of mature differentiated oligodendrocytes and demyelination under the influence of the cuprizone in vitro [28]. It was found that cuprizone-induced demyelination is associated with a loss of oligodendrocytes with subsequent inhibition of the myelin formation. During this work, which continue the previous studies, we studied the direct action 

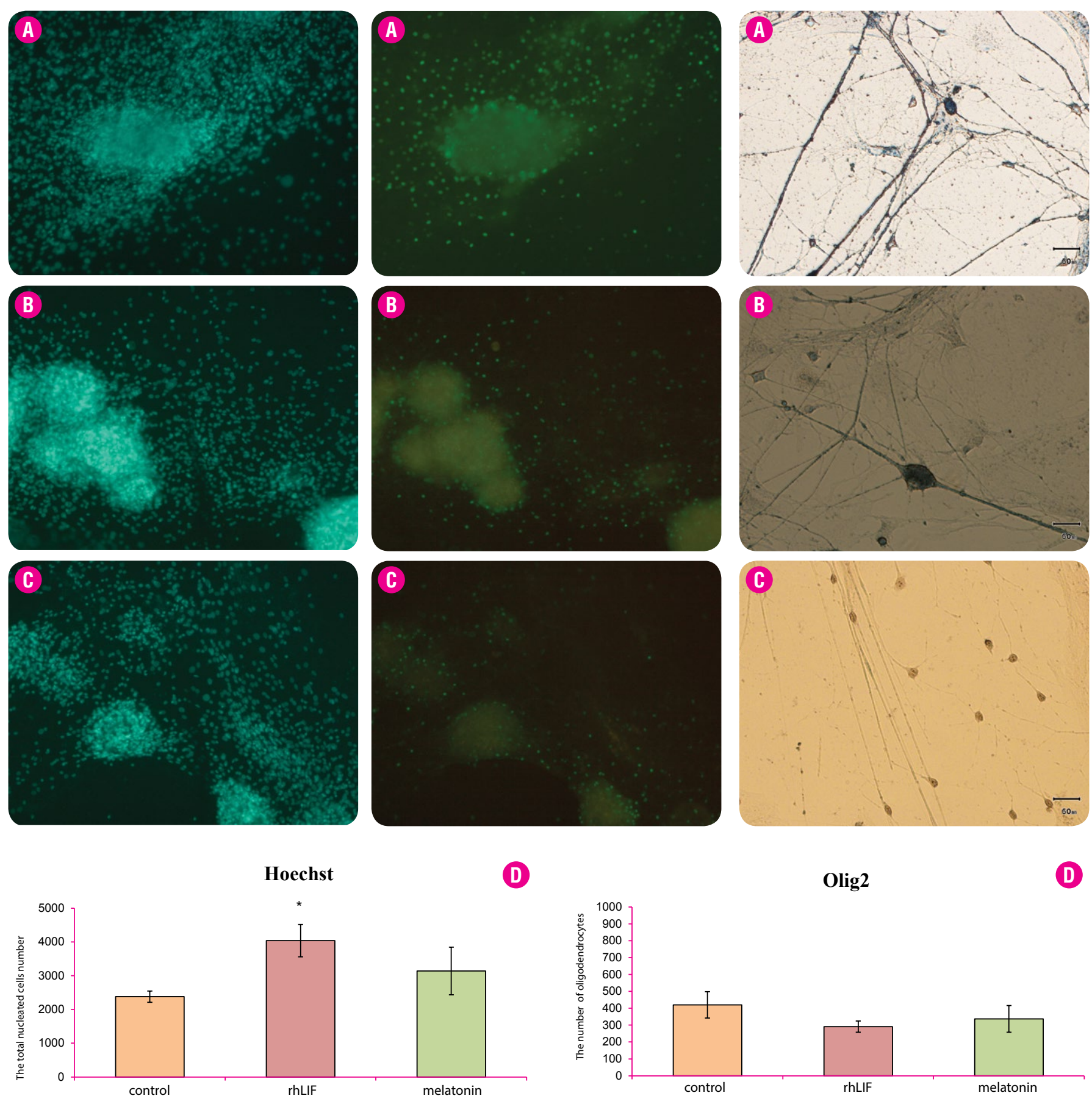

A Fig. 1. Microphotographs of the dissociated culture of the cerebellar cells on the 28-30th days of cultivation: control cultures (A), cultures with $20 \mathrm{ng} / \mathrm{mL}$ rhLIF (B) or $10 \mu \mathrm{g} / \mathrm{mL}$ melatonin (C). Fluorescent microscopy, immunocytochemical staining for Hoechst 33342 (turquoise) and Olig2 (green). Light microscopy: staining of axon myelin shells with Sudan black B, x200. Histograms of the total number of nucleated cells by Hoechst and Olig2+ oligodendrocytes (D)

Note: * $-p<0.05$ compared with control group.

of biologically active agents (rhLIF and melatonin) on remyelination using the cuprizone-induced model of toxic demyelination in vitro [30].

We have found that rhLIF without previous cuprizone introduction into the culture increases the total number of nucleated cells in the dissociated cerebellar cells culture in comparison to the control cultures, but the number of oligodendrocytes does not change under the influence of this factor (Fig. 1). However, the addition of melatonin to the culture medium did not lead to significant changes in both the amount of Olig2+ and the to- tal number of nucleated cells compared to control cultures (Fig. 1). Thus, it can be assumed that only the multifunctional cytokine LIF affects the proliferative potential of neural cells under normal conditions.

At the same time, the addition of rhLIF to the culture for 3 days at a concentration of $20 \mathrm{ng} / \mathrm{mL}$ or $10 \mu \mathrm{g} / \mathrm{mL}$ melatonin after the cuprizone treatment resulted in an increase in both the number of oligodendrocytes and the total amount of nucleated cells compared to the cultures treated with cuprizone. Moreover, the treatment of cultures with $25 \mu \mathrm{M}$ cuprizone for 

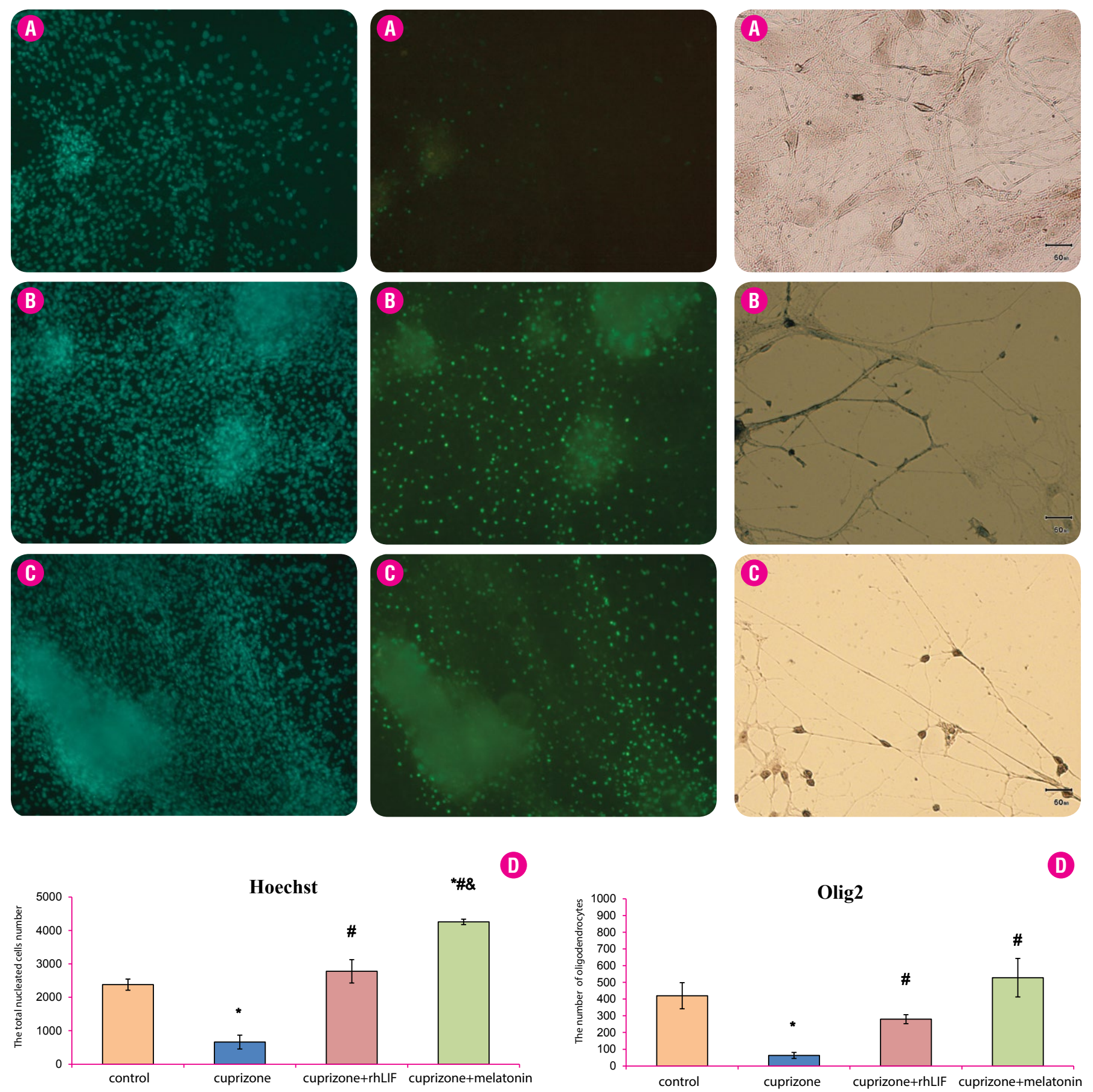

Fig. 2. Microphotographs of the dissociated cerebellar cells culture on the 28-30th days of cultivation: the cultures treated with cuprizone (A), cultures treated with cuprizone and $20 \mathrm{ng} / \mathrm{mL}$ rhLIF (B) or $10 \mu \mathrm{g} / \mathrm{mL}$ melatonin (C). Fluorescent microscopy, immunocytochemical staining for Hoechst 33342 (turquoise) and Olig2 (green). Light microscopy: staining of axon myelin shells with Sudan black B, x200. Histograms of the total number of nucleated cells by Hoechst and Olig2+ oligodendrocytes (D).

Note: ${ }^{*}-p<0.05$ compared to control group; \# $-p<0.05$ compared to cuprizone-treated group; $\&-p<0.05$ compared to cuprizone + rhLIF group.

48 hours followed by the addition of rhLIF or melatonin for 3 days induced an increase in the total number of cells in 4.2 and 6.4 times, respectively, compared to cultures treated with cuprizone only (Fig. 2).

In addition, the total number of cells was significantly higher $(p<0.05)$ in cultures treated with cuprizone and melatonin compared to cultures under the influence of cuprizone + rhLIF and control cultures. Perhaps, this is due to the effect of melatonin on the activation of antioxidant enzymes, which, on the one hand, reduces damage to brain neurons, and, on the other hand, provides conditions for reparative processes in the brain involving T-lymphocytes. The study of Abdurasulova I. and Klimenko V. showed that T-lymphocytes play a double role in the action on the nervous tissue and manifestation of their damaging effects on the brain neurons are related precisely to the components of oxidative stress and proinflammatory cytokines [31]. At the presence of rhLIF or melatonin, the number of oligodendrocytes in cultures pre-treated with cuprizone increased by 4.4 times (from $62.5 \pm 18.8$ to $279.8 \pm 26.8$ cells) and 8.4 times (from 
$62.5 \pm 18$, 8 to $528.2 \pm 115.4$ cells), respectively (Fig. 2). Since Olig2 is a transcription factor that is required for myelin activation, specifically for the expression of the myelin regulatory factor (MyRF), which in its turn regulates myelin-associated proteins [32,33], our studies have shown the recovery of myelin membranes. Thus, rhLIF and melatonin prevented the loss of oligodendrocytes and, consequently, reduced the destruction of myelin sheaths.

The cuprizone model of demyelination in vitro is a relatively simple and useful model for studying the processes associated with de- and re- myelination in the central nervous system (in particular, in the cerebellum), and it solves the problem of finding remyelinating factors in order to restore myelination of axons. The results of restoration of myelin production in the demyelinated culture of the cerebellar cells under the influence of rhLIF and melatonin allow to assess the state of remyelination of the cerebellar neuron axons, which is important for the study of the demyelinating diseases pathogenesis, in particular multiple sclerosis, and to expand the list of drugs with remyelinating effect.

\section{CONCLUSION}

There was an increase in the total number of cells in the culture of murine cerebellar cells without cuprizone treatment after the addition of recombinant rhLIF. The addition of rhLIF or melatonin did not affect the amount of Olig2+ oligodendrocytes.

In the culture of the murine cerebellar cells treated with cuprizone, when the pineal hormone melatonin was added, the total number of cells was significantly higher than with rhLIF application. At that, the amount of Olig2 ${ }^{+}$oligodendrocytes, reduced under the impact of the cuprizone, was restored.

\section{REFERENCES}

1. Melnik NO. Struktura deyakikh organiv nervovoï ta imunnoï sistem za umov demielinizatsiï ta remielinizatsiï [The structure of some organs of the nervous and immune systems in condition of demyelination and remyelination]. Medical Doctorate Thesis. Kyiv, 2005. 358 p. [In Ukrainian]

2. Pivneva TA. Mekhanizmy demielinizatsii pri rasseyannom skleroze. [Mechanisms of demyelination in multiple sclerosis]. Neyrofiziologiya - Neurophysiology. 2009. 41(5):429-437. [In Russian]

3. Suslina ZA, Zavalishin IA. Rasseyannyy skleroz: ot predstavleniy o patogeneze $\mathrm{k}$ lecheniyu [Multiple sclerosis: from pathogenesis concepts to treatment]. Nevrologicheskiy vesnik - Neurological journal. 2010; 1:6-8. [In Russian]

4. Mishchenko TS, Shulga OD. Bobryk NV, et al. Rozsiyanyy skleroz: hlobal'ni perspektyvy [Multiple sclerosis: the global perspective]. Ukrainskiy medichniy chasopis Ukrainian medical journal. 2014; 101(3):84-87. [In Ukrainian]

5. Abakumova TO, Kuzkin AA, Zharova MV, et al. Kuprizonovaya model' kak instrument dlya doklinicheskogo issledovaniya effektivnosti diagnostiki i terapii rasseyannogo skleroza [Cuprizone model as a tool for preclinical studies of the effectiveness of multiple sclerosis diagnosis and therapy]. Byull eksperim biologii i med - Bulletin of Experimental Biology and Medicine. 2015; 159(1):124-129. [In Russian]

6. Praet J, Guglielmetti C, Berneman Z, et al. Cellular and molecular neuropathology of the cuprizone mouse model: Clinical relevance for multiple sclerosis. Neurosci Biobehav Rev. 2014; 47:485-505

7. Acs P, Kalman B. Pathogenesis of multiple sclerosis: what can we learn from the cuprizone model. Methods Mol Biol. 2012; 900:403-431.

8. Kipp M, Clarner T, Dang J, et al. The cuprizone animal model: new insights into an old story. Acta Neuropathol. 2009; 118(6):723-736.

9. Labunets IF. Struktura deyakikh organiv nervovoï ta imunnoï sistem za umov demiєlinizatsiï ta remiєlinizatsiï [Possibilities and prospects of the application of the in vivo and in vitro toxic cuprizone model for demyelination in experimental and clinical neurology (literature review and own research results)]. Ukraïns'kiy nevrologichniy zhurnal - Ukrainian Neurological Journal. 2018; 2:63-68. [In Ukrainian]

10. Andrew JA, Zhang H, Bauer N, et al. In vitro modeling of central nervous system myelination and remyelination. In: Glia. 2012; 60(1):1-12.

11. Zhang $H$, Jarjour $A A$, Boyd $A$, et al. Central nervous system remyelination in culture - A tool for multiple sclerosis research. Experimental Neurology. 2011; 230:138148 DOI:10.1016/j.expneurol.2011.04.009.

12. Rymar SYu, Novikova SM, Irodov DM, et al. Perspektivi vikoristannya u meditsini faktora ingibuvannya leykemii ta stvorennya yogo produtsenta [Prospects for the use in medicine of the Leukemia inhibitory factor and the creation of its producer]. Zhurn. AMN Ukraïni - Journal AMS of Ukraine. 2010; 16(2):199-212. [In Ukrainian]

13. Deverman $B$, Patterson $P$. Exogenous leukemia inhibitory factor stimulates oligodendrocyte progenitor cell proliferation and enhances hippocampal remyelination. J Neurosci. 2012; 32(6):2100-2109.

14. Schmitz T, Chew L. Cytokines and myelination in the central nervous system. Scientific World Journal. 2008; 2(8):1119-1147.

15. Gudi V, Gingele S, Skripuletz Th, et al. Glial response during cuprizon-induced de- and remyelination in the CNS: lessons learned. Frontiers in cellular neuroscience. 2014; $8(73): 24$

16. Majumder A, Banerjee S, Harrill JA, et al. Neurotrophic effects of leukemia inhibitory factor on neural cells derived from human embryonic stem cells. Stem Cells. 2012; 30(11):2387-2399.

17. Marriott MP, Emery B, Cate HS, et al. Leukemia inhibitory factor signaling modulates both central nervous system demyelination and myelin repair. Glia. 2008; 56:686698.

18. Labunets LF. Melnyk NJ, Rodnichenko $A E$, et al. Cuprizone-induced disorders of central nervous system neurons, behavioral reactions, brain activity of macrophages and antioxidant enzymes in mice of different ages: Role of Leukemia Inhibitory Factor in their improvement. JAging Geriatr Med. 2017; 1:1-8. D0l: 10.4172/ AGM.1000104.

19. Zozulya Yu. A., Lisyany N. I. Neyrogennaya differentsirovka stvolovykh kletok [Neurogenic differentiation of stem cells]. Kiev, 000 UIPK «Eks0b», $2005.368 \mathrm{p}$. [In Russian]

20. Karaaslan C, Suzen S. Antioxidant properties of melatonin and its potential action in diseases. Current topics in medicinal chemistry. 2015; 15(9):894-903.

21. Reiter RJ, Manchestr LC, Tan DX. Neurotoxins: free radical mechanisms and melatonin protection. CurrNeuropharmacol. 2010; 8(3):194-210.

22. Tomas-Zapico CA, Coto-Montes A. A proposed mechanisms to explain the stimulatory effect of melatonin on antioxidative enzymes. J Pineal Res. 2005; 39(2):99-104.

23. Kashani IR, Rajabi Z, Akbari M, et al. Protective effects of melatonin against mitochondrial injury in a mouse model of multiple sclerosis. Exp Brain Res. 2014; 232(9):2835-2846.

24. Moriya T, Horie N, Mitome M, et al. Melatonin influences the proliferative and differentiative activity of neural stem cells. J Pineal Res. 2007; 42(4):411-418. 
25. Srinivasan V. Therapeutic potential of melatonin and its analogs in Parkinson's disease: focus on sleep and neuroprotection. Ther Adv Neurol Disord. 2011; 4(5):297317.

26. Talanov SA, Sagach VF. Antioksidanti prignichuyut' rozvitok eksperimental'nogo gemiparkinsonizmu u shchuriv [Antioxidants inhibit the development of experimental hemiparkinsonism in rats]. Fiziologichnyi zhurnal. 2008; 54(4):23-29. [In Ukrainian]

27. Gutierrer-Valdez AL, Anaya-Martinez V, Ordonez-Librado JL, et al. Effect of chronic L-Dopa or melatonin treatments after dopamine deafferentation in rats: dyskinesia, motor performance, and cytological analysis. ISRN Neurology. 2012; 2012:1-16.

28. Rodnichenko A. Implementation of a toxic cuprizone model of demyelination in vitro. Cell and Organ Transplantology. 2018; 6(1):93-98.

29. Layton MJ, Lock $P$, Metcaff $D$, et al. Cross-species receptor binding characteristics of human and mouse leukemia inhibitory factor suggest a complex binding interaction. J Biol Chem. 1994. 269(25):17048-17055.

30. Rodnichenko A, Utko N, Labunets I, et al. In vitro cuprizone model as a tool to study remyelination factors. $11^{\text {th }}$ FENS Forum of neuroscience (7-11 July 2018 , Berlin, Germany), Abstract number F18-0774.

31. Abdurasulova IN, Klimenko VM. Rol' immunnykh i glial'nykh kletok v protsessakh neyrodegeneratsii [The role of immune and glial cells in the processes of neurodegeneration]. 2011; 11(1):12-29. [In Russian]

32. Goldman SA, Kuypers NJ. How to make an oligodendrocyte. Development. 2015; 142:3983-3995.

33. Patel JR, Klein RS. Mediators of oligodendrocyte differentiation during remyelination. FEBS Letters. 2011; 585:3730-3737.

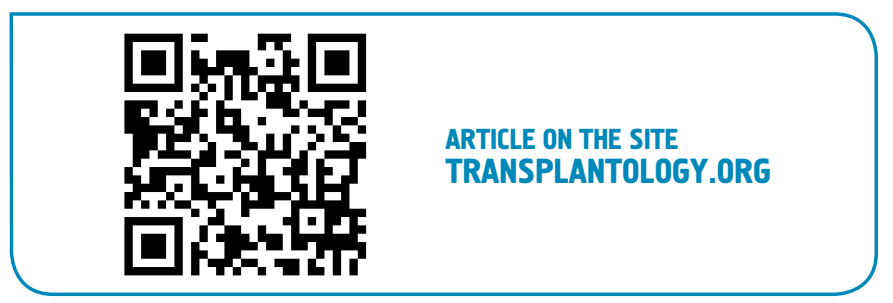

The authors indicate no potential conflicts of interest.

Received: September 05, 2018

Accepted: November 30, 2018 